\title{
Analisis Konsistensi Perencanaan dan Penganggaran Urusan Pendidikan di Kota Solok Tahun 2016-2019
}

\author{
Sridarnilawati, Suhairi, Vima Tista Putriana \\ Jurusan Akuntansi, Fakultas Ekonomi dan Bisnis, Universitas Andalas Padang \\ Correspondence email: nilasridarnilawati@gmail.com
}

\begin{abstract}
Abstrak. Penyusunan dokumen Perencanaan dan penganggaran sangat berkontribusi terhadap capai kinerja daerah. Konsistensi perencanaan dan penganggran merupakan indikator dalam menilai kinerja pemerintah daerah. Objek penelitian ini adalah urusan pendidikan. Urusan pendidikan mendapatkan prioritas utama bagi pemerintah daerah Kota Solok. Hal ini ditujukan anggaran untuk urusan pendidikan mencapai lebih dari 20\% dari seluruh anggaran belanja daerah. Jenis data yaitu data sekunder dan data primer. Data sekunder yaitu RPJMD, RKPD, KUA, PPAS dan APBD dan LAKIP sedangkan data primer yaitu melalai wawancara kepada Anggota Tim Anggaran Pemerintah Daerah (TAPD), BAPPEDA dan OPD yang bertanggungjawab terhadap Urusan Pendidikan. Penilaian konsistensi perencanaan dan penganggaran menggunakan Matrik Konsolidasi Perencanaan dan Penganggaran (MKPP) dan penyebab tidak konsistennya dilakukan wawancara kepada informan yang mahami dan mengetahui hal tersebut. Hasil dari penelitian ini Konsistensi perencanaan dan penganggaran urusan pendidikan sangat baik. Penyebab tidak konsistennya dokumen perencanaan dan penganggaran adalah usulan Dana Alokasi Khusus (DAK) yang diusulkan tidak disetujui oleh Pemerintah Pusat, Adanya intervensi Pemerintahan dan Anggota Dewan, Adanya peraturan dari Pemerintah Pusat. Analisis capaian kinerja urusan pendidikan di Kota Solok menunjukkan bahwa secara umum pencapaian indikator urusan pendidikan belum tercapai karena capaian indikator setiap tahunnya menurut.
\end{abstract}

Kata Kunci: Konsistensi; Perencanaan; Penganggaran

\begin{abstract}
The preparation of planning and budgeting documents greatly contributes to the achievement of regional performance. Consistency in planning and budgeting is an indicator in assessing the performance of local governments. The object of this research is educational affairs. Education affairs are given top priority for the local government of Kota Solok. It is intended that the budget for education affairs reaches more than $20 \%$ of the total regional expenditure budget. Types of data are secondary data and primary data. Secondary data are RPJMD, RKPD, KUA, PPAS and APBD and LAKIP while primary data is neglecting to interview members of the Regional Government Budget Team (TAPD), BAPPEDA and OPD who are responsible for Educational Affairs. Assessment of the consistency of planning and budgeting uses the Planning and Budgeting Consolidated Matrix (MKPP) and the causes of inconsistency are interviews with informants who understand and know this. The results of this research consistency of planning and budgeting for educational affairs is very good. The causes of inconsistency in planning and budgeting documents are that the proposed Special Allocation Fund (DAK) was not approved by the Central Government, the intervention of the Government and Members of the Council, the existence of regulations from the Central Government. Analysis of the achievement of the performance of education affairs in the City of Solok shows that in general the achievement of the indicators of education affairs has not been achieved because the achievement of indicators according to each year is.
\end{abstract}

Keywords: Consistency; Planning; Budgeting

\section{PENDAHULUAN}

Dengan diterapkannya otonomi daerah di Indonesia sejak tahun 2001, denganberlakunya undangundang nomor 22 Tahun 1999, telah terjadi perubahan tata kelola keperintahan yang signifikan di Indonesia, dari yang awalnya bersifat sentralistik menjadi terdesentraliasasi (Waris,2012). Perubahan sistem ini menyebabkan pemerintah daerah menerima tanggungjawab yang jauh lebih besar dalam hal penyelengggaraan pelayanan publik dibanding dengan sebelum otonomi daerah. Tujuan dari otonomi daerah adalah untuk mendekatkan pemerintah kepada rakyat dan mempercepat peningkatan kesejahteraan masyarakat setempat (Mardiasmo, 2002). Dalam rangka mewujudkan tujuan otonomi daerah ini, pemerintah daerah menyusun berbagai program dan kegiatan setiap tahunnya yang diturunkandari Rencana Pembangunan Jangka Menengah Daerah (RPJMD).
Perencanaan pembangunan daerah sendiri dapat dipahami sebagai proses penyusunan tahapan kegiatan yang melibatkan berbagai unsur pemangku kepentingan didalamnya, guna pemanfaatan dan pengalokasian sumber daya yang ada dalam rangka meningkatkan kesejahteraan sosial dalam suatu lingkungan wilayah/daerah dalam jangka waktu tertentu. Menurut Fitry (2012) tentang Analisis Konsistensi Perencanaan dan Penganggaran Bidang Kesehatan Kota Lubuklinggau Tahun 2010. Hasil penelitiannya menunjukan tingkat konsistensi perencaranaan dan penganggaran kurang baik, hal ini disebabkan pimpinan daerah kurang memiliki komitmen dan sering mutasi pejabat daerah serta kurangnya kemampuan pejabat perencanaan.

Pembangunan pendidikan mendapat prioritas tertinggi dalam pembangunan di Kota Solok. Hal ini ditunjukkan oleh penyediaan anggaran pembangunan bidang pendidikan selama kurun waktu (2010-2015) 
yang mencapai lebih dari $20 \%$ dari keseluruhan belanja daerah. Ini merupakan wujud komitmen Pemerintah Daerah dalam melaksanakan UUD 1945 dan UndangUndang Nomor 20 Tahun 2003 tentang Sistem Pendidikan Nasional dalam alokasi anggaran pendidikan dari Anggaran Pendapatan dan Belanja Negara (APBN) atau Anggaran Pendapatan dan Belanja Daera (APBD). Hal ini sehubungan dengan tujuan dari Pemerintah Daerah Kota Solok untuk meningkatkan kualitas sumberdaya manusia yang beriman, sehat, kreatif dan berdaya saing dengan sasaran meningkatnya tingkat pendidikan masyarakat dan pemerataan kualitas pendidikan.

Konsistensi perencanaan dan penganggaran penting diperhatikan karena merupakan indikator dalam menilai kinerja pemerintah daerah, agar seluruh program dan kegiatan pemerintah yang telah ditetapkan berjalan dengan baik dan tercapai. Konsistensi antara perencanaan dan penganggaran penting diperhatikan karena akan membawa implikasi terhadap kinerja pemerintah daerah (Osrinda dan Delis, 2016).

Dari latar belakang ada beberapa permasalahan yang dapat dirumuskan dalam penelitian ini yaitu: 1) Bagaimana konsistensi antara perencanaan dengan penganggaran urusan pendidikan di Kota Solok tahun 2016-2019? 2) Apa faktor-faktor yang mempengaruhi konsistensi perencanaan dengan penganggaran urusan pendidikan di Kota Solok tahun 2016-2019? 3) Bagaimana capaian target kinerja Urusan Pendidikan di Kota Solok tahun 2016-2019? 4) Bagaimana implikasi dari konsistensi perencanaan dan penganggaran terhadap capaian target kinerja Urusan Pendidikan di Kota Solokk sehingga tercapai sasaran dan tujuan yang diinginkan.

\section{Tinjauan Literatur \\ Definisi Perencanaan Daerah}

Menurut Abe (2002) pengertian perencanaan daerah ada 2 macam:

1. Perencanaan daerah sebagai suatu bentuk perencanaan pembangunan yang merupakan implementasi atau penjabaran dari perencanaan pusat. Dalam hal ini, bisa terjadi dua kemungkinan yaitu :
a. Perencanaan daerah adalah bagian dari perencanaan pusat,

b. Perencanaan daerah adalah penjelasan mengenai rencana pusat yang diselenggarakan di daerah. Proses penyusunannya bisa dilakukan melalui top down atau bottom up.

2. Perencanaan daerah sebagai suatu kemungkinan yaitu a. Perencanaan daerah sebagi rumusan murni kepentingan daerah tanpa mengindahkan koridor dari pusat dan

b. Perencanaan daerah tidak lebih sebagai kesempatan yang diberikan pusat untuk diisi oleh daerah.
Dari pengertian di atas yang sesuai dengan Sistem Perintahan di Indonesia adalah Penyelenggaraan pemerintahan daerah lebih menekankan pada prinsip demokrasi, peran serta masyarakat, pemerataan dan keadilan serta memperhatikan potensi dan keanekaragaman daerah. Pelaksanaan perencanaan daerah yang menitikberatkan pada Daerah Kabupaten dan Daerah Kota dimulai dengan adanya penyerahan sejumlah kewenangan (urusan) dari Pemerintah Pusat ke Pemerintah Daerah yang bersangkutan. Dalam perencanaan daerah harus terintegrasi dengan perencanaan Pemerintah Pusat yang dilakukan melalui melalui top down atau bottom up atau diperlukan koordinasi antarinstansi pemerintah dan partisipasi seluruh pelaku pembangunan, melalui suatu forum yang disebut sebagai Musyawarah Perencanaan Pembangunan (Musrenbang). Sebagaimana diatur dalam Peraturan Menteri Dalam Negeri Nomor 86 Tahun 2017 tentang Tata Cara Perencanaan, Pengendalian Dan Evaluasi Pembangunan Daerah, Tata Cara Evaluasi Rancangan Peraturan Daerah Tentang Rencana Pembangunan Jangka Panjang Daerah Dan Rencana Pembangunan Jangka Menengah Daerah, Serta Tata Cara Perubahan Rencana Pembangunan Jangka Panjang Daerah, Rencana Pembangunan Jangka Menengah Daerah, Dan Rencana Kerja Pemerintah Daerah.

\section{Defenisi penganggaran daerah}

Menurut Shoulder dan Freeman (2003), anggaran merupakan proses yang dilakukan oleh pemerintah daerah untuk mengalokasikan sumber daya yang dimilikinya pada kebutuhan-kebutuhan yang tidak terbatas. Anggaran diukur dalam finansial dan sebagai pernyataan mengenai estimasi kinerja yang hendak dicapai selama periode waktu tertentu. Sedangkan penganggaran adalah perencanaan yang digambarkan secara kuantitatif dalam bentuk keuangan dan ukuran kuantitatif lainnya (Supriyono, 2002). sedangkan penganggaran menurut Mardiasmo (2009) mengartikan sebagai proses atau metode untuk mempersiapkan suatu anggaran. Jadi penganggaran daerah merupakan alat perencanaan sekaligus alat pengendalian pemerintahan.

$$
\text { Anggaran sebagai alat perencanaan }
$$
mengindikasikan target yang harus dicapai oleh pemerintahan, sedangkan penganggaran sebagai alat pengendalian mengindikasikan alokasi sumber dana publik yang disetujui legislatif untuk dibelanjakan. Anggaran pemerintahan daerah merupakan pengelolaan dana masyarkat, karenanya dituntut adanya transparansi dan akuntabilitas kepada masyakarat (Hermawan, 2011). Halim dan Kusufi (2016) menambahkan penganggaran di daerah adalah jumlah alokasi dana untuk masingmasing program dan kegiatan dalam satuan anggaran. Apabila pemerintahan mampu merumuskan dan merencanakan strategis dengan baik dan bijaksana, maka tujuan pemerintahan yang telah disepakati akan tercapai. 


\section{Pengukuran Kinerja Organisasi Pemerintah Daerah}

Menurut Niven (2003) terdapat enam konsep pengukuran kinerja organisasi sektor publik dan organisasi non profit, yaitu:

1. Financial accountability

Financial accountability adalah pengukuran kinerja organisasi sektor publik yang hanya berfokus pada seberapa besar anggaran yang telah dikeluarkan.

2. Program products or outputs

Program products or outputs adalah pengukuran kinerja organisasi sektor publik bergantung pada jumlah produk atau jasa dihasilkan dan beberapa jumlah orang yang dilayani.

3. Adherence to standards quality in service delivery Pengukuran kinerja yang terkonsentrasi pada pelayanan yang mengarah pada ketentuan badan sertifikasi dan akreditasi pemerintah. Badan tersebut juga bertujuan untuk menjaga kualitas dan konsistensi produk atau jasa yang mereka berikan.

\section{Participant related measures}

Pengukuran kinerja yang menekankan pentingnya kepastian pemberian pelayanan hanya kepada mereka yang sangat membutuhkan, oleh karena itu organisasi sektor publik akan melakukan penilaian klien atau pelanggan yang akan dilayani berdasarkan status demografinya, sehingga bisa ditentukan mana pelanggan yang layak mendapatkan pelayanan terlebih dahulu.

\section{Key performance indicators}

Pengukuran kinerja yang berdasarkan pada pembentukan kriteria-kriteria tertentu yang dapat mewakili semua area yang ingin dinilai, untuk kemudian disusun indikator-indikator yang mampu mengukur kriteria tersebut.

6. Client satisfaction

Pengukuran kinerja organisasi publik didasarkan pada kepuasan pelanggan atas penyediaan barang atau pelayanan publik. Beberapa faktor utama yang menentukan kepuasan pelanggan, yaitu ketepatan waktu pelayanan, kemudahan untuk mendapat layanan dan kepuasan secara keseluruhan.

Pengukuran kinerja yang menjadi dasar dalam penelitian ini adalah menurut teori Niven (2003) bagaimana menilai kinerja sektor publik. Teori Niven menyatakan yang pertama akuntabilitas anggaran dapat dilakukan dengan menilai seberapa besar dan efektif serapan anggaran dalam menjalankan program yang telah ditetapkan. Kedua, hasil program bukan hanya melihat output dan input, tetapi juga melihat outcome dan output. Ketiga, menguji hasil suatu program sesuai dengan aturan standar yang berlaku. Keempat, menilai dengan bagaimana sektor publik dalam memberi pelayanan kepada masyarakat yang membutuhkan. Konsep kelima mengenai indikator kunci juga bisa menjadi dasar pengukuran kinerja sektor publiki. Terakhir terkait kepuasan dalam memperoleh layanan dari sektor publik.

\section{Indikator unrusan pendidikan kota solok}

Beberapa standar indikator pendidikan yang dapat dievaluasi sebagai berikut:

1. Indeks Pembangunan Manusia (IPM)

IPM adalah pengukuran perbandingan dari harapan hidup, melek huruf, pendidikan dan standar hidup. IPM menjelaskan bagaimana penduduk dapat mengakses hasil pembangunan dalam memperoleh pendapatan, kesehatan, pendidikan, dan sebagainya. IPM diperkenalkan oleh Program Pembangunan Perserikatan Bangsa-Bangsa (UNDP) pada tahun 1990 dan dipublikasikan secara berkala dalam laporan tahunan Human Development Report (HDR). IPM digunakan untuk mengklasifikasikan apakah sebuah negara adalah negara maju, negara berkembang atau negara terbelakang dan juga untuk mengukur pengaruh dari kebijaksanaan ekonomi terhadap kualitas hidup. IPM memiliki tiga dimensi yang digunakan sebagai dasar perhitungannya: a. Kesehatan, yang diukur dengan angka harapan hidup saat kelahiran b. Pendidikan, yang dihitung dari angka harapan sekolah dan angka rata-rata lama sekolah. c. Standar hidup layak, yang dihitung dari produk nasional bruto per kapita

2. Angka Partisipasi Kasar (APK)

APK merupakan proporsi jumlah penduduk yangsedang bersekolah pada suatu jenjang pendidikan terhadap jumlah penduduk usiasekolah yang sesuai dengan jenjang pendidikan tersebut. Nilai APK bisa lebih dari100 persen karena populasi murid yang bersekolah pada suatu jenjang pendidikanmencakup anak di luar batas usia sekolah pada jenjang pendidikan yang bersangkutan (misal anak bersekoah SD berumur kurang dari 7 tahun atau lebih dari 12 tahun). Secara umum, APK digunakan untuk mengukur keberhasilan program pembangunan pendidikan yang diselenggarankan dalam rangka memperluas kesempatan bagi penduduk untuk mengenyam pendidikan.

3. Angka Partisipasi Murni (APM)

APM merupakan proporsi jumlah anak pada kelompok usia sekolah tertentu yang sedang bersekolah pada jenjang pendidian yang sesuai dengan usianya terhadap jumlah seluruh anak pada kelompok usia sekolah yang bersangkutan. Sebagai gambaran misalnya APM SD adalah proporsi jumlah murid SD yang berusia 7-12 tahun terhadap jmlah seluruh anak yangberusia 7-12 tahun

4. Pengertian rata-rata lama sekolah

Rata-rata lama sekolah adalah jumlah tahun belajar penduduk usia 15 tahun $\mathrm{ke}$ atas yang telah diselesaikan dalam pendidikan formal (tidak termasuk tahunyang mengulang). Untuk menghitung rata-rata lama sekolah dibutuhkan informasi tentang: partisipasi sekolah, jenjang dan jenis pendidikan tertinggi yang pernah/sedang diduduki, ijasah tertinggi yang dimiliki, tingkat/kelas tertinggi yang 
pernah/sedang diduduki. Untuk melihat kualitas penduduk dalam hal mengenyampendidikan formal. Batas maksimum untuk rata-rata lama sekolah adalah 15 tahun dan batas minimum sebesar 0 tahun (standar UNDP).

5. Ujian Nasional (UN)

UN merupakan suatu penilaian untuk mengetahui apakah rumusan tujuan pendidikan yang diterjemahkan ke dalam kurikulum dapat dicapai atau tidak. Guza (2008) mengemukakan bahwa Ujian Nasional pada hakekatnya berbasis hasil (outputbased) dan hasil belajar siswa diukur dengan menggunakan standar nasional yang mengacu pada kurikulum nasional pula sehingga Ujian Nasional pada hakikatnya merupakan bentuk ujian berdasarkan ketentuan berlaku.

\section{METODE}

Metode penelitian yang digunakan dalam penelitian ini adalah metode kualitatif. Metode kualitatif merupakan penelitian yang menggunakan landasan teori dalam menganalisis hasil penelitian untuk mendeskripsikan hasil riset. Sedangkan jenis penelitian yang digunakan adalah case study atau studi kasus. Studi kasus yang dirumuskan oleh Robert K. Yin, merupakan sebuah metode yang mengacu pada penelitian yang mempunyai unsur how dan why, pada pertanyaan utama penelitiannya meneliti masalah-masalah kontemporer (masa kini) dalam kehidupan nyata.

Jenis data dalam penelitian ini menggunakan data sekunder dan data primer. Data sekunder adalah data yang dikeluarkan oleh dinas/instansi terkait yang ada di Kota Solok, berupa RPJMD, RKPD, KUA, PPAS dan APBD Kota Solok dan Laporan Akuntabilitas Kinerja Instansi Pemerintah (LAKIP) Kota Solok. Sedangkan data primer diperoleh melalui wawancara dengan pejabat yang terkait dalam proses penyusunan perencanaan dan penganggaran pada Pemerintah Daerah Kota Solok, khususnya OPD yang bertanggungjawab terhadap urusan Pendidikan di Kota Solok.

Teknik Pengumpulan Data dalam penelitian ini, penulis menggunakan Kajian Dokumen Data Sekunder dan Wawancara langsung dengan informan melalui proses tanya jawab secara lisan. Nara sumber yang terkait dalam penelitian ini, yaitu diantaranya: Anggota Tim Anggaran Pemerintah Daerah (TAPD) Kota Solok, Pejabat Badan Perencanaan Pembangunan Daerah Kota Solok serta OPD yang bertanggungjawab terhadap urusan pendidikan di Kota Solok.

AnalisisKonsistensi antara Perencanaan dan Penganggaran Urusan Pendidikan Kota Solokn dilakukan dengan mengevaluasi program dan kegiatan dalam dokumen perencanaan dan penganggaran yang disusun dengan membuat matrik konsolidasi perencanaan dan penganggaran (MKPP) programkegiatan Urusan Pendidikan di Kota Solok.

MKPP merupakan alat bantu untuk mengkonsolidasikan dokumen perencanaan dan penganggaran secara menyeluruh. Sehingga konsistensi antar dokumen perencanaan dan penganggaran Urusan Pendidikan di Kota Solok akan terlihat apakah terjadi sinkronisasi dan sinergitas.

Penyusunan Matrik Konsolidasi Perencanaan dan Penganggaran program-kegiatan dilakukan dengan integrasi antara dua dokumen, yakni:

a. Integrasi RPJMD dengan RKPD

b. Integrasi RKPD dengan KUA

c. Integrasi KUA dengan PPAS

d. Integrasi RKPD dengan APBD

e. Integrasi PPAS dengan APBD

Pengelompokkan konsistensi untuk lebih mudahnya dapat dilihat pada Tabel berikut:

Pengelompokkan Konsistensi Program dan Kegiatan

\begin{tabular}{cccc}
\hline No. & \multicolumn{2}{c}{ Program/Kegiatan } & Pengelompokkan \\
\cline { 2 - 3 } & Dokumen A & Dokumen B & Konsistensi \\
\hline 1. & Ada & Ada & Konsisten \\
2. & Ada & Tidak ada & Tidak Konsisten \\
3. & Tidak ada & Ada & Tidak Konsisten \\
\hline
\end{tabular}

Sumber : Meldayeni 2011

Berdasarkan penentuan konsistensi tersebut dapat dikelompokkan jumlah program dan kegiatan yang konsisten dan tidak konsisten. Selanjutnya untuk menentukan tingkat konsistensi secara keseluruhan dari dokumen tersebut dilakukan melalui teknik persentase yaitu :

Tingkat konsistensi (\%)Program $=\frac{\text { Jumlah Program yang konsisten } \times 100 \%}{\text { Total Program }}$

Tingkat konsistensi (\%)Kegiatan $=\frac{\text { Jumlah Kegiatan yang konsisten } \times 100 \%}{\text { Total Kegiatan }}$

Metoda Deskriptif untuk mengetahui faktor-faktor yang mempengaruhi konsistensi

Setelah Untuk mengatahui penyebab program dan kegiatan yang tidak konsisten, dilakukan wawancara mendalam (indept interview). Penentuan konsistensi rencana dan anggaran juga dilakukan berdasarkan besarnya budget yang dianggarkan. Untuk program dan kegiatan yang telah konsistensi secara nomenklatur, seterusnya dilihat konsistensi berdasarkan deviasi anggaran. Hal ini dapat dilihat pada Gambar berikut : 


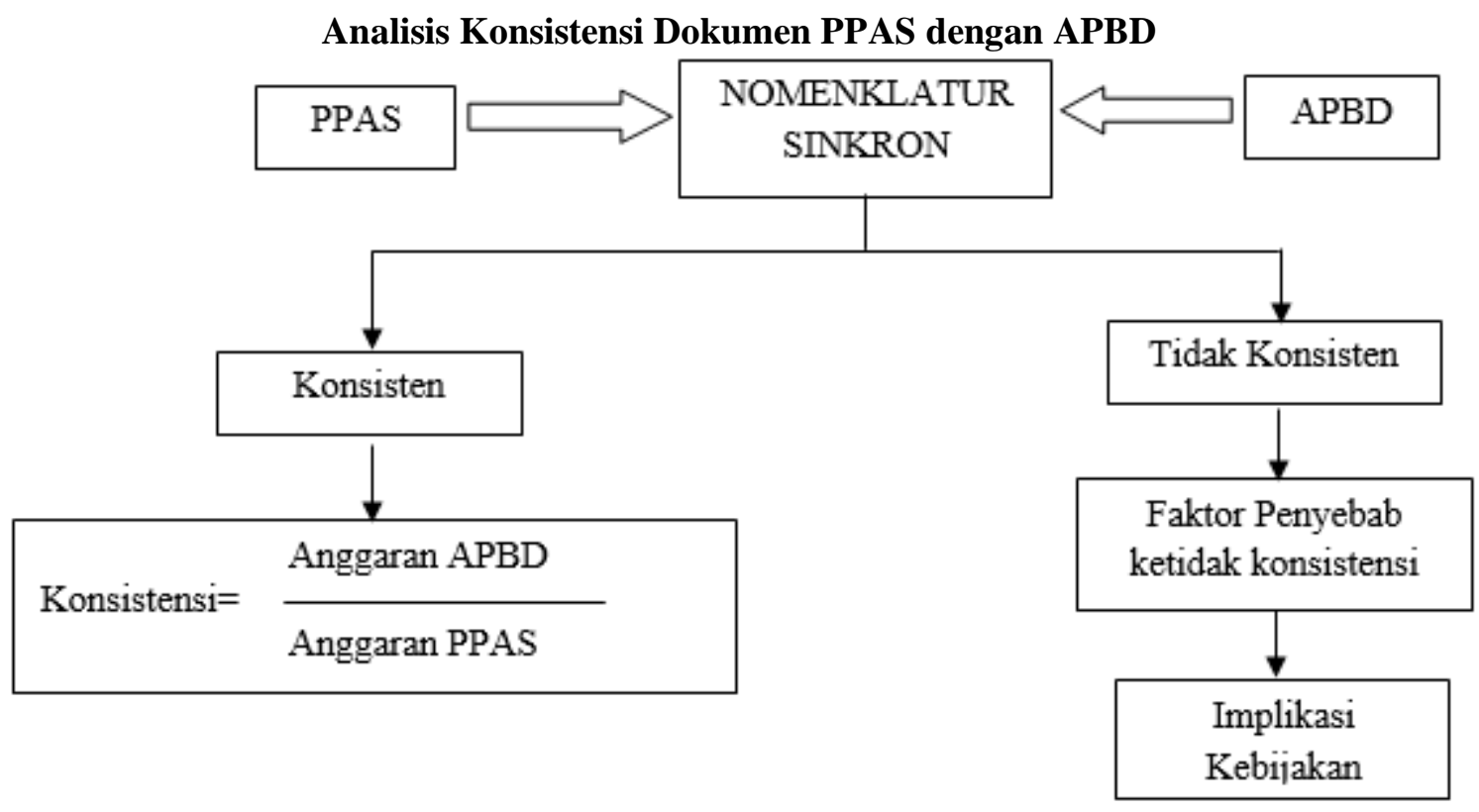

Sumber : Meldayeni 2011

Konsistensi anggaran alokasi PPAS dengan alokasi APBD dapat dihitung dengan memperbandingkan anggaran PPAS denga APBD, untuk mengetahui jumlah deviasi anggaran yaitu APBD dikurangi anggaran PPAS, presentase deviasi anggaran dihitung dengan jumlah deviasi anggaran dibagi anggaran PPAS dikali $100 \%$.

Selanjutnya untuk mengetahui jumlah dan persentase (\%) deviasi anggaran untuk program dan kegiatan yang telah konsistensi secara nomenklatur disajikan seperti tabel dibawah ini

Deviasi Anggaran Kegiatan Urusan PendidikanKota Solok di dalam PPAS danAPBD.

\begin{tabular}{|c|c|c|c|c|c|}
\hline \multirow{2}{*}{ No } & Program & PPAS & \multicolumn{2}{c|}{ APBD } & \multicolumn{2}{c|}{ Deviasi Anggaran } \\
\cline { 3 - 6 } & /Kegiatan yang Konsisten & $(\mathrm{Rp})$ & $(\mathrm{Rp})$ & $(\mathrm{Rp})$ & $\%$ \\
\hline 1. & & & & & \\
\hline 2. & & & & & \\
\hline 3. & & & & & \\
\hline 4. & & & & & \\
\hline 5. & Dst.... & & & & \\
\hline \multicolumn{2}{|l|}{ Total }
\end{tabular}

Menganalisi Capaian Target Kinerja Urusan Pendidikan yang dituangkan pada LAKIP Kota Solok

Untuk menganalisis capaian target kinerja Urusan Pendidikandi Kota Solok dilakukan dengan menganalisisrealisasi pencapaian sasaran Urusan Pendidikan dalam RPJMD Kota Solok Tahun 2016-2019 yaitu Menigkatnya tingkat pendidikan masyarakat dan pemerataan kualitas pendidikan.

Menyusun Implikasi dari konsistensi perencanaan dan penganggaran terhadap capaian target kinerja Urusan Pendidikan di Kota Solok

Berdasarkan hasil dari temuan tingkat konsistensi dan penyebab terjadinya ketidakkonsistenan serta capaian target kinerja urusan pendidikan disusun implikasi kebijakan sehingga tercapai sasaran dan tujuan yang diinginkan.

HASIL DAN PEMBAHASAN

Analisis Konsistensi Perencanaan dan Penganggaran Urusan Pendidikan dikota Solok

Analisis konsistensi perencanaan dan penganggaran dianalisis berdasarkan konsistensi antara dokumen RPJMD, RKPD, KUA, PPAS, dan APBD. 
Sridarnilawati, Suhairi dan Vima Tista Putriana, Analisis Konsistensi Perencanaan dan Penganggaran Urusan Pendidikan di Kota Solok Tahun 2016-2019

\section{Konsistensi Dokumen RPJMD dengan RKPD tahun 2016-2019}

\begin{tabular}{|c|c|c|c|c|c|c|c|c|c|c|}
\hline \multirow{2}{*}{ No } & \multirow{2}{*}{\multicolumn{2}{|c|}{ Status program/kegiatan }} & \multicolumn{2}{|c|}{2016} & \multicolumn{2}{|c|}{2017} & \multicolumn{2}{|c|}{2018} & \multicolumn{2}{|c|}{2019} \\
\hline & & & Prog & Keg & Prog & Keg & Prog & Keg & Prog & Keg \\
\hline \multirow{2}{*}{1.} & \multirow{2}{*}{ Konsisten } & $\overline{\mathrm{Jml}}$ & 8 & - & 8 & - & 7 & - & 7 & - \\
\hline & & $\%$ & 100 & - & 88,89 & - & 100 & - & 100 & - \\
\hline \multirow{2}{*}{2.} & \multirow{2}{*}{ Tdk Konsisten } & $\mathrm{Jml}$ & - & - & 1 & - & - & - & - & - \\
\hline & & $\%$ & - & - & 11,11 & - & - & - & - & - \\
\hline
\end{tabular}

Dari tabel diatas menunjukkan tingkat konsistensi yang sangat baik pada program RKPD yaitu $100 \%$ untuk tahun 2016,2018,dan 2019 dengan masing-masing program 8 untuk tahun 2016, 7 program untuk tahun
2018 dan 2019. Sedangkan untuk tahun 2017 terdapat 9 program dengan 8 program atau $88,89 \%$ yang konsisten dan 1 program atau $11,11 \%$ yang tidak konsisten. Dalam penyusunan RKPD telah berpedoman pada RPJMD.

\section{Konsistensi Dokumen RKPD denganKUA tahun 2016-2019}

\begin{tabular}{|c|c|c|c|c|c|c|c|c|c|c|}
\hline \multirow{2}{*}{ No } & \multirow{2}{*}{\multicolumn{2}{|c|}{ Status program/kegiatan }} & \multicolumn{2}{|c|}{2016} & \multicolumn{2}{|c|}{2017} & \multicolumn{2}{|c|}{2018} & \multicolumn{2}{|c|}{2019} \\
\hline & & & Prog & Keg & Prog & Keg & Prog & Keg & Prog & Keg \\
\hline \multirow{2}{*}{1.} & \multirow{2}{*}{ Konsisten } & $\mathrm{Jml}$ & 8 & 57 & 9 & 48 & 7 & 41 & 7 & 49 \\
\hline & & $\%$ & 100 & 98,3 & 100 & 97,96 & 100 & 100 & 100 & 100 \\
\hline \multirow{2}{*}{2.} & \multirow{2}{*}{ Tdk Konsisten } & $\mathrm{Jml}$ & - & 1 & - & 1 & - & - & - & - \\
\hline & & $\%$ & - & 1,72 & - & 2,04 & - & - & - & - \\
\hline
\end{tabular}

Dari tabel diatas menunjukkan tingkat konsistensi untuk program sangat baik yaitu $100 \%$ dengan 8 program ditahun 2016,9 program untuk 2017,7 program untuk tahun 2018 dam 2019. Sedangkan untuk tahun2016 kegiatan terdapat 58 kegiatan 57 konsisten atau $89,30 \%$ dan 1 tidak konsisten atau 1,72\%dan untuk tahun 2017 terdapat 49 kegiatan 48 konsisten atau $97,96 \%$ serta 1 tidak konsisten atau $1,72 \%$ yang tidak konsisten.

\section{Konsistensi Dokumen KUA dengan PPAS tahun 2016-2019}

\begin{tabular}{|c|c|c|c|c|c|c|c|c|c|c|}
\hline \multirow{2}{*}{ No } & \multirow{2}{*}{\multicolumn{2}{|c|}{ Status program/kegiatan }} & \multicolumn{2}{|c|}{2016} & \multicolumn{2}{|c|}{2017} & \multicolumn{2}{|c|}{2018} & \multicolumn{2}{|c|}{2019} \\
\hline & & & Prog & Keg & Prog & Keg & $\overline{\text { Prog }}$ & Keg & Prog & Keg \\
\hline \multirow{2}{*}{1.} & \multirow{2}{*}{ Konsisten } & Jml & 8 & 58 & 9 & 49 & 7 & 41 & 7 & 49 \\
\hline & & $\%$ & 100 & 100 & 100 & 100 & 100 & 100 & 100 & 100 \\
\hline \multirow{2}{*}{2.} & \multirow{2}{*}{ Tdk Konsisten } & Jml & - & - & - & - & - & - & - & - \\
\hline & & $\%$ & - & - & - & - & - & - & - & - \\
\hline
\end{tabular}

Dari tabel diatas menunjukkan bahwa tingkat konsistensi program dan kegiatan sangat baik yaitu 100\% dengan 8 program 58 kegiatan ditahun 2016, 9 program 49 kegiatan ditahun 2017, 7 program 41 kegiatan ditahun 2018 dan 7 program 49 kegiatan ditahun 2019.

Konsistensi dokumen RKPD dengan APBD tahun 2016-2019

\begin{tabular}{|c|c|c|c|c|c|c|c|c|c|c|}
\hline \multirow{2}{*}{ No } & \multirow{2}{*}{\multicolumn{2}{|c|}{ Status program/kegiatan }} & \multicolumn{2}{|c|}{2016} & \multicolumn{2}{|c|}{2017} & \multicolumn{2}{|c|}{2018} & \multicolumn{2}{|c|}{2019} \\
\hline & & & Prog & Keg & Prog & Keg & Prog & Keg & Prog & Keg \\
\hline \multirow{2}{*}{1.} & \multirow{2}{*}{ Konsisten } & $\mathrm{Jml}$ & 8 & 50 & 8 & 37 & 7 & 41 & 7 & 52 \\
\hline & & $\%$ & 100 & 100 & 100 & 84,09 & 100 & 95,35 & 100 & 89,66 \\
\hline \multirow{2}{*}{2.} & \multirow{2}{*}{ Tdk Konsisten } & $\mathrm{Jml}$ & - & - & - & 7 & - & 2 & - & 6 \\
\hline & & $\%$ & - & - & - & 15,91 & - & 4,65 & - & 10,34 \\
\hline
\end{tabular}

Dari tabel diatas menunjukkan tingkat konsistensi untuk program sangat baikyaitu $100 \%$ persen di tahun 2016 dengan 8 program ,ditahun 2017 dengan 8 program,ditahun 2018 dan 2019 dengan 7 program. Sedangkan untuk tahun 2016 terdapat 50 kegiatan dengan konsistensi 100\%, ditahun 2017 terdapat 44 kegiatan dengan 27 kegiatan atau 84,09\% yang konsisten dan 7 atau 15,91\% yang tidak konsisten. Pada thun 2018 terdapat 43 kegiatan dengan 41 atau $95,35 \%$ yang konsisten 2 atay $4,65 \%$ yang tidak konsisten. Serta pada tahun 2019 terdapat 58 kegiatan dengan 52 atau 89,66\% yang konsisten 6 atau 10,34\% yang tidak konsisten. 
Sridarnilawati, Suhairi dan Vima Tista Putriana, Analisis Konsistensi Perencanaan dan Penganggaran Urusan Pendidikan di Kota Solok Tahun 2016-2019

Konsistensi dokumen PPAS dengan APBD tahun 2016-2019

\begin{tabular}{|c|c|c|c|c|c|c|c|c|c|c|}
\hline \multirow{2}{*}{ No } & \multirow{2}{*}{\multicolumn{2}{|c|}{ Status program/kegiatan }} & \multicolumn{2}{|c|}{2016} & \multicolumn{2}{|c|}{2017} & \multicolumn{2}{|c|}{2018} & \multicolumn{2}{|c|}{2019} \\
\hline & & & Prog & Keg & Prog & Keg & Prog & Keg & Prog & Keg \\
\hline \multirow{2}{*}{1.} & \multirow{2}{*}{ Konsisten } & Jml & 8 & 50 & 8 & 38 & 7 & 41 & 7 & 47 \\
\hline & & $\%$ & 100 & 100 & $100^{\circ}$ & 86,36 & 100 & 95,35 & 100 & 81,03 \\
\hline \multirow{2}{*}{2.} & \multirow{2}{*}{ Tdk Konsisten } & Jml & - & - & - & 6 & - & 2 & - & 11 \\
\hline & & $\%$ & - & - & - & 13,64 & - & 4,65 & - & 18,97 \\
\hline
\end{tabular}

Dari tabel diatas menunjukkan bahwa tingkat konsistensi untuk program sangat baik yaitu $100 \%$ di tahun 2016-2019. Sedangkan untuk kegiatan pada tahun 2016 memiliki 50 kegiatan dengan konsistensi 100\%, tahun 2017 terdapat 44 kegiatan 38 atau 86,36\% yang konsisten 6 kegiatan atau 13,64\% yang tidak konsisten, ditahun 2018 terdapat 43 kegiatan 41 atau 95,35\% yang konsisten 2 kegiatan atau 4,65\% yang tidak konsisten, serta ditahun 2019 terdapat 58 kegiatan dengan 47 atau $81,03 \%$ yang konsisten 11 atau $18,97 \%$ yang tidak konsisten.

Berdasarkan nomenklatur semua program dan kegiatan yang konsisten, selanjutnya untuk kegiatan yang konsisten, berdasarkan budget yang telah dianggarkan dalam dokumen PPAS dan APBD akan dihitung deviasinya, dapat dilihat pada table dibawah ini.

\begin{tabular}{|c|c|c|c|c|c|}
\hline NO & Uraian & 2016 & 2017 & 2018 & 2019 \\
\hline 1 & Deviasi Anggaran (Rp) & 3.822 .151 .764 & 2.865 .363 .125 & 4.871 .868 .450 & $(836.650 .767)$ \\
\hline 2 & Presentase Deviasi (\%) & 8,18 & 18,66 & 23 & -10 \\
\hline
\end{tabular}

Dari tabel ini atas dapat disimpulkan Rata-rata presentase deviasi anggaran urusan pendidikan Kota Solok tahun 2016-2019 adalah 8,18\% tahun 2016, $18,66 \%$ tahun $2017,23 \%$ tahun 2018 dan $-10 \%$ pada tahun 2019, tahun 2019 menurun sangat signifikat, hal ini disebabkan anggaran banyak dialihkan ke Pembangunan Rumah Sakit Daerah Kota Solok, Pembangunan GOR dan Persiapan MTQ Tingkat Nasional. ini merupakan prioitas pembangunan menjelang pemilihan Kepala Dearah.

Faktor-faktor yang mempengaruhi tidak konsistennya perencanaan dan Penganggaran Urusan Pendidikan di kota Solok

Dari hasil penelitian ini yang menyebabkan tidak konsistenya antara lain :

a. Kegiatan yang diusulkan menggunakan Dana Alokasi Khusus yang diterima oleh Pemerintah Daerah tidak disetujui oleh Pemerintah Pusat. Hal ini diketahui setelah dokumen perencanaan selesai disusun. .

b. Tahun 2017 Program Bantuan Operasional Sekolah mulai masuk dalam dokumen perencanaan dengan dasar adanya Peraturan Menteri Penidikan dan Kebudayaan Nomor 8 Tahun 2017 tentang Petunjuk Teknis Bantuan Operasional Sekolah.

c. Adanya Undang-Undang Nomor 23 Tahun 2014 tentang Pemerintah Daerah lampiran Pembagian Urusan Pemerintahan konkuren antara Pemerintah Pusat dan Daerah Provinisi dan Daerah Kabupaten/Kota Urusan Pendidikan dijelaskan bahwa kewenangan Pengelolaan Pendidikan Menengah merupakan kewenangan Pemerintah Provinsi. Ketentuan ini mulai diterapkan pada tahun 2016.

d. Program yang ada di RPJMD hanya untuk menampung tahun sebelum. Hal ini diperkuat
Perubahan peraturan perencanaan pembangunan pemerintah pusat diawali dengan terbitnya Undangundang Nomor 23 Tahun 2014 tentang Pemerintah Daerah dan Peraturan Pemerintah Nomor 18 Tahun 2016 tentang Perangkat Daerah. Untuk pelaksanaan urusan hanya boleh 1 (satu) OPD. Program Peningkatan kualitas pendidikan masyarakat yang beriman dan bertaqwa, dan Program Peningkatan pelayanan kehidupan beragama dilaksanakan oleh Sekretariat Daerah Bagian Kesra sesuai dengan Tugas Pokok OPD.

e. Adanya intervensi Pemerintah dan Anggota Dewan guna mengutamakan Prioritas Pembangunan sebelum pemilihan Kepala Daerah.

\section{Pencapaian Target Kinerja Urusan Pendidikan di Kota Solok Tahun 2016-2019. \\ Capaian target kinerja Urusan Pendidikan Kota Solok Tahun 2016}

Berdasarkan hasil penelitian, capaian dari 3 (tiga) indikator sasaran Meningkatnya Tingkat Pendidikan Masyarakat dan Pemerataan Kualitas Pendidikan sampai dengan Tahun 2016 yang merupakan tahun pertama pelaksanaan RPJMD 2016-2021 secara akumulasi telah tercapai $87,98 \%$. Akan tetapi, terdapat satu indikator yang masih sangat rendah tingkat capaiannya yaitu angka putus sekolah SMA/MA/SMK yang hanya tercapai $16 \%$.

Disebabkan karena faktor sosial dan budaya masyarakat, seperti adanya siswa pendidikan menengah yang tidak mau menyelesaikan sekolahnya dengan alasan bekerja membantu perekonomian orang tua, meskipun pemerintah Kota Solok telah menyediakan beberapa program untuk meningkatkan partisipasi sekolah antara lain: Program Bantuan Operasional 
Manajemen Mutu (BOMM), Bantuan siswa miskin (BSM) dan program paket C setara SMA.

\section{Capaian target kinerja Urusan Pendidikan Kota Solok Tahun 2017}

Berdasarkan hasil evaluasi pencapaian sasaran di atas, capaian dari 2 (dua) indikator sasaran Meningkatnya Tingkat Pendidikan Masyarakat dan Pemerataan Kualitas Pendidikan sampai dengan Tahun 2017 secara akumulasi telah tercapai $71,77 \%$. Terdapat satu indikator yang capaian kinerjanya masih $0 \%$ yaitu indikator Persentase sekolah dengan rata-rata hasil UN $\mathrm{SMP} \geq 6,0$.

Hal ini disebabkan kurangnya kemampuan guru mata pelajaran Bahasa Inggris, IPA dan Matematika SMP (Mata Pelajaran UN) karena yang memegang Mata Pelajaran UN adalah guru non PNS yang tentu saja secara pertanggungjawaban tidak dapat di tuntut sebagaimana guru PNS

\section{Capaian target kinerja Urusan Pendidikan Kota Solok Tahun 2018}

Berdasarkan hasil evaluasi pencapaian sasaran di atas, capaian dari 2 (dua) indikator sasaran Meningkatnya Tingkat Pendidikan Masyarakat dan Pemerataan Kualitas Pendidikan sampai dengan Tahun 2018 secara akumulasi telah tercapai 67,54\%. Terdapat 1 (satu) indikator yang mencapai $100 \%$ dan 2 (dua) indikator belum dapat mencapai $100 \%$ yaitu $50 \%$ untuk indikator Persentase sekolah dengan rata-rata hasil UN $\mathrm{SD} \geq 7,7$ dan 51,33\% untuk indikator Persentase sekolah dengan rata-rata hasil $\mathrm{UN} \mathrm{SMP} \geq 6,0$.

Hal ini disebabkan antara lain karena adanya perubahan metode soal ujian, dimana tahun 2018 telah menerapkan metode Higher Order Thinking Skills (HOTS)/tingkat kesulitan soal. Metode ini merupakan metode pengujian dengan memakai tingkat kesulitan soal untuk menguji kemampuan siswa dalam memecahkan masalah, berfikir kreatif, beargumen serta kemampuan mengambil keputusan. Siswa belum terbiasa dengan metode pengujian seperti ini, sehingga menyebabkan nilai rata-rata UN lebih rendah dari tahun sebelumnya

\section{Capaian target kinerja Urusan Pendidikan Kota Solok Tahun 2019}

Berdasarkan hasil evaluasi pencapaian sasaran di atas, capaian dari 2 (dua) indikator sasaran Meningkatnya Tingkat Pendidikan Masyarakat dan Pemerataan Kualitas Pendidikan sampai dengan Tahun 2019 secara akumulasi telah tercapai $60,66 \%$. Terdapat satu indikator yang capaian kinerjanya masih $0 \%$ yaitu indikator Persentase sekolah dengan rata-rata hasil UN $\mathrm{SMP} \geq 6,0$.

Hal ini sebabkan Ujian Nasional tidak dijadikan penentu kelulusan sehingga keseriusan siswa dan guru dalam menyiapkan diri menghadapi ujian nasional berkurang dan rendahnya motivasi guru yang sudah lama mengajar disatu sekolah. Kelulusan siswa sepenuhnya ditentukan oleh masing-masing sekolah melalui rapat dewan guru.

\section{Implikasinya dari konsistensi perencanaan dan penganggaran TerhadapCapaian Target Kinerja Urusan Pendidikan Kota Solok}

Berdasarkan analisis konsistensi perencanaan dan penganggaran yang dilakukan dapat dikemukakan beberapa hal berikut:

a. Tingkat konsisten perencanaan dengan penganggaran untuk tahun 2016-2019 sangat baik. Namun tidak untuk capaian target kinerja urusan pendidikan dimana mengalami penurunan setiap tahunnya.

b. Pada Tahun 2016 terdapat satu indikator yang masih sangat rendah tingkat capaiannya yaitu angka putus sekolah SMA/MA/SMK yang hanya tercapai $16 \%$.

c. Indikator capaian kinerjanya masih $0 \%$ untuk indikator Persentase sekolah dengan rata-rata hasil UN SMP $\geq 6,0$ untuk tahun 2017 dan 2019. Disamping kemampuan guru yang ada, jumlah guru mata pelajaran yang kurang hal ini disebabkan tidak adanya menerimaan PNS mulai Tahun 2015- 2017. Kekurangan guru ini ditutupi oleh guru non PNS yang tentu saja secara pertanggungjawaban tidak dapat di tuntut sebagaimana guru PNS.

d. Ada 2 (dua) indikator belum dapat mencapai $100 \%$ pada tahun 2018 yaitu 50\% indikator Persentase sekolah dengan rata-rata hasil $\mathrm{UN} \mathrm{SD} \geq 7,7$ dan $51,33 \%$ indikator Persentase sekolah dengan rata-rata hasil UN SMP $\geq 6,0$. Dimana tahun 2018 telah menerapkan metode Higher Order Thinking Skills (HOTS)/tingkat kesulitan soal.

e. Tingginya tingkat capaian kinerja indikator untuk Angka Putus Sekolah disebabkan karena sudah semakin tingginya tingkat kesadaran masyarakat akan arti pentingnya pendidikan bagi anak-anak mereka

f. Tingginya tingkat capaian dari angka kelulusan SD/MI ini disebabkan karena adanya program belajar tambahan pada pagi dan sore hari bagi setiap siswa calon peserta UASBN untuk setiap mata pelajaran selama satu semester.

\section{SIMPULAN}

Dari penelitian yang dilakukan maka dapat disimpulkan hal sebagai berikut:

1. Konsistensi antara perencanaan dengan penganggaran urusan pendidikan di Kota Solok tahun 2016-2019 adalah sebagai berikut:

a. Konsistensi Program yang ada RPJMD terhadap program yang ada pada RKPD adalah $100 \%$ tahun $2016,88,89 \%$ tahun $2017,100 \%$ pada tahun 2018 dan 2019.

b. Konsistensi program dan kegiatan yang ada pada RKPD terhadap program dan kegiatan yang ada pada KUA adalah $100 \%$ dan $98,28 \%$ pada tahun 
2016, $100 \%$ dan $97,96 \%$ pada tahun $2017,100 \%$ dan 100\% pada tahun 2018 dan 2019.

c. Konsistensi program dan kegiatan yang ada pada KUA terhadap PPAS adalah 100\% untuk program dan kegiatan pada tahun 2016-2019.

d. Konsistensi program dan kegiatan yang ada pada RKPD terhadap program dan kegiatan yang ada pada APBD adalah $100 \%$ dan $100 \%$ tahun 2016, $100 \%$ dan $84,09 \%$ pada tahun $2017,100 \%$ dan $95,35 \%$ pada tahun $2018,100 \%$ dan $89,66 \%$ pada tahun 2019.

e. Konsistensi program dan kegiatan yang ada pada PPAS terhadap program dan kegiatan yang ada pada APBD adalah $100 \%$ dan $100 \%$ tahun 2016, $100 \%$ dan $86,36 \%$ pada tahun $2017,100 \%$ dan $95,35 \%$ pada tahun $2018,100 \%$ dan $81,03 \%$ pada tahun 2019

2. Dalam penelitian masih terdapat ada program dan kegiatan yang tidak konsisten. Ketidakkonsistenan setiap tahunnya disebabkan karena :(a) Kegiatan yang diusulkan menggunakan DAK tidak disetujui oleh Pemerintah Puast, (b) Adanya Undang-Undang Nomor 23 Tahun 2014 tentang Pemerintah Daerah dijelaskan bahwa kewenangan Pengelolaan Pendidikan Menengah merupakan kewenangan Pemerintah Provinsi, (c) Program yang ada di RPJMD hanya untuk menampung tahun sebelum. Hal ini diperkuat dengan terbitnya Undang-undang Nomor 23 Tahun 2014 tentang Pemerintah Daerah dan Peraturan Pemerintah Nomor 18 Tahun 2016 tentang Perangkat Daerah. Untuk pelaksanaan urusan hanya boleh 1 '(satu) OPD, (d) Adanya kegiatan yang baru merupakan intervensi Pemerintah dan Anggota Dewan karena mengutamakan Prioritas Pembangunan sebelum pemilihan Kepala Daerah, (e) Adanya kegiatan dengan tujuan dan sasaran yang sama.

3. Rata-rata presentase deviasi anggaran urusan pendidikan Kota Solok tahun 2016-2019 adalah $8,18 \%$ tahun $2016,18,66 \%$ tahun $2017,23 \%$ tahun 2018 dan $-10 \%$ pada tahun 2019, tahun 2019 menurun sangat signifikat, hal ini disebabkan anggaran banyak dialihkan ke Pembangunan Rumah Sakit Daerah Kota Solok, Pembangunan GOR dan Persiapan MTQ Tingkat Nasional. ini merupakan prioitas pembangunan menjelang pemilihan Kepala Dearah.

4. Capaiantarget kinerja urusan pendidikan kota solok berdasarkan dokumen RPJMD 2016-2021 dengan sasaran meningkatnya tingkat pendidikan masyarakat dan pemerataan kualitas pendidikan adalah $87,60 \%$ tahun 2016, 71,77\% tahun 2017, 67,54\% tahun 2018 dan 60,66\% tahun 2019.

5. Pencapaianurusan pendidikan di Kota Solok yang merupakan sasaran untuk ururan pendidikan yang tertuang dalam RPJMD Kota Solok Tahun 20162021,untuk tahun 2016 terdapat 1 indikator Angka
Putus Sekolah yang belum tercapai sasarannya hanya 16\%. Hal ini disebabkan karena faktor sosial dan budaya masyarakat, seperti adanya siswa pendidikan menengah yang tidak mau menyelesaikan sekolahnya dengan alasan bekerja membantu perekonomian orang tua.Tahun 2017-2019 terdapat 1 indikator ratarata hasil UN SMP $(\geq 6,0)$ belum tercapai sasaran atau $0,00 \%$ untuk tahun 2017 dan 2019. Disebabkan kurangnya kemampuan guru mata pelajaran yang di UN kan disamping itu Ujian Nasional tidak dijadikan penentu kelulusan sehingga keseriusan siswa dan guru dalam menyiapkan diri menghadapi ujian nasional berkurang dan rendahnya motivasi guru yang sudah lama mengajar disatu sekolah. Kelulusan siswa sepenuhnya ditentukan oleh masing-masing sekolah melalui rapat dewan guru.

\section{Rekomendasi}

Dalam rangka melaksanakan program dan kegiatan untuk pencapai target kinerja urusan pendidikan yang dituangkan dalam RPJMD Kota Solok Tahun 2016-2021 harus meningkatkan Sumber Daya Manusia agar program dan kegiatan yang telah ditetapkan berjalan dengan baik dan tercapai. Sedangkan tingkat konsistensi antara perencanaan dan penganggaran untuk urusan Pendidikan di Kota Solok yang sangat baik agar dapat di optimalkan lagi.

\section{DAFTAR PUSTAKA}

Abe, A. 2002. Perencanaan daerah partisipati. Penerbit Pondok Edukasi. Solo

Fitry, R. 2012. Analisis Konsistensi Perencanaan dan Penganggaran Bidang Kesehatan Kota Lubuklinggau Tahun 2010. Tesis, Program Magister Perencanaan dan Kebijakan Publik, Fakultas Ekonomi Universitas Indonesia.

Freeman, RJ \& Shoulder, C.D. 2003. Governmental Nonprofit accounting : Theory and Practice. Upper Saddle River, NJ: Prentice Hall

Halim, A dan Kusufi, M, S. 2016. Akuntansi Sektor Publik. Edisi Kedua. Jakarta: Salemba Empat.

Hermawan, E. 2011. Analisis Penerapan Sistem Anggaran Berbasis Kinerja Di Lingkungan Rumah Tangga Kepresidenan-Sekretariat Negara Republik Indonesia. Fakultas Ekonomi Program Magister Perencanaan dan Kebijakan Publik. Universitas Indonesia.

Mardiasmo. 2002. Otonomi dan Manajemen Keuangan Daerah: Penerbit Andi

Mardiasmo. 2009. Akuntansi Sektor Publik. Edisi Keempat. Yogyakarta: Penerbit Andi

Meldayeni. 2011.Analisis Konsistensi Perencanaan dan Penganggaran Bidang Kesehatan di Kota Solok Tahun 2007-2010. Tesis Pasca Sarjana Universitas Andalas. 
Niven, P. R. 2003. Balanced Scorecard: Step-By-Step for Government and Nonprofit Agencies. New York: John Wiley \& Sons, Inc

Osrinda, N dan Delis, A. 2016. Analisis Konsistensi Perencanaan dan Penganggaran serta Implikasinya terhadap Capaian Target Kinerja pada Badan Perencanaan Pembangunan Daerah Kabupaten Merangin. Jurnal Perspektif Pembiayaan dan Pembangunan Daerah. Volume 3, Nomor 3

Peraturan Menteri Dalam Negeri Nomor 86 Tahun 2017 tentang Tata Cara Perencanaan, Pengendalian Dan Evaluasi Pembangunan Daerah, Tata Cara Evaluasi Rancangan Peraturan Daerah Tentang Rencana Pembangunan Jangka Panjang Daerah Dan Rencana Pembangunan Jangka Menengah Daerah, Serta Tata Cara Perubahan Rencana Pembangunan Jangka Panjang Daerah, Rencana Pembangunan Jangka Menengah Daerah, Dan Rencana Kerja Pemerintah Daerah

Pemerintah Daerah Kota Solok, Laporan Akuntabilitas Kinerja Instansi Pemerintah (LAKIP) Kota Solok Tahun 2016-2019.

Pemerintah Daerah Kota Solok, Rencana Pembangunan Jangka Menengah (RPJM) Daerah Pemerintah Daerah Kota Solok periode 2016-2021.

Pemerintah Daerah Kota Solok, Rencana Kerja Pemerintah Daerah(RKPD) Kota Solok Tahun 2016 sampai dengan Tahun 2019.

Pemerintah Daerah Kota Solok, Kebijakan Umum Anggaran (KUA) Kota Solok Tahun 2016 sampai dengan Tahun 2019.

Pemerintah Daerah Kota Solok, Prioritas dan Plafon Anggaran Sementara (PPAS) Kota Solok Tahun 2016-2019.

Pemerintah Daerah Kota Solok, Anggaran Pendapatan dan Belanja Daerah (APBD) Kota Solok Tahun 2016 sampai dengan Tahun 2019.

Supriyono. 2002. Akuntansi Biaya dan Akuntansi Manajemen. Fakultas Ekonomi Univeraitas Gadjah Mada. Yogyakarta.

Undang-Undang Nomor 20 Tahun 2003 tentang Sistem Pendidikan Nasional

Waris. I. 2012. Pergeseran Paradigma Sentralisasi ke Desentralisasi Dalam Mewujudkan Good Governance. Program Studi Ilmu Pemerintahan FISIP Universitas Tadulako. Sulawesi Tengah.

Yin, R. K. (2013) Case Study Research: Design and Methods. 4th Edition, Sage Publications, Thousand Oaks. 